\title{
Tabanca namlu malzemesi 32CrMoV12-10 alaşımına uygulanan gaz nitrasyon ve su verme işlemlerinin darbe dayanımına etkilerinin incelenmesi
}

\author{
Investigation of the impact strength of gas nitration and quenching processes applied to gun \\ barrel material 32CrMoV12-10 alloy
}

\author{
Mahmutcan KARSLI ${ }^{* 1,2, a}$, Ŭgur KEMİKLİĞLU ${ }^{3, b}$, Samet YAVUZ ${ }^{1,4, c}$ \\ ${ }^{1}$ Girsan Makina ve Hafif Silah Sanayi Ticaret A.Ş., 28100, Giresun \\ ${ }^{2}$ Karadeniz Teknik Üniversitesi Mühendislik Fakültesi, Makine Mühendisliği Bölümü, 61080, Trabzon \\ ${ }^{3}$ Doğus Üniversitesi, Mühendislik Fakültesi, Makine Mühendisliği Bölümü, 34775, İstanbul \\ ${ }^{4}$ Ondokuz Mayıs Üniversitesi Mühendislik Fakültesi, Makine Mühendisliği Bölümü, 55270, Samsun
}

• Geliş tarihi / Received: 06.11.2020 • • Düzeltilerek geliş tarihi / Received in revised form: 14.01.2021 • Kabul tarihi / Accepted: 14.08 .2021

$\ddot{O} \mathbf{z}$

Savunma sanayi, ülkeler için vazgeçilmez bir alan olmakla birlikte önemi her geçen gün daha da artmaktadır. Bu kapsamda sanayinin çoğu alanlarında olduğu gibi savunma sanayisinde de iyileştirme çalışmaları son yıllarda hız kazanmıştır. Bu çalışmada ülkemiz savunma sanayisi teknolojisinin geliştirilmesine ve savunma sanayisi alanında bilgi birikimi oluşturulmasına katkı sağlanması amaçlanmıştır. Namlu, hafif silahlarda tabancanın kullanım ömrüne doğrudan etki eden silah ana parçalarının başında gelmektedir. Bu yönüyle tabanca namlusuna uygulanacak 1sıl işlem tabancanın direk olarak ömrüne etki etmektedir. Bu çalışmada hafif silah endüstrisinde namlu imalatında yaygın olarak kullanılan dövülmüş haldeki 32CrMoV12-10 (1.7765) malzemeden oluşturulan numunelere, hali hazırda namlulara uygulanan geleneksel su verme işlemi ve son yıllarda uygulama alanı genişleyen gaz nitrasyon yöntemi olmak üzere 2 tip 1sıl işlem uygulaması yapılmış ve bu uygulamaların numunelere etkileri deneysel olarak incelenmiştir. Yapılan deneysel çalışmaların sonuçları incelendiğinde gaz nitrürlenmiş numunelerin yüzey sertliklerinin, su verme işlemi uygulanan numunelerden yaklaşık 1.5 kat daha fazla olduğu buna karşılık içyapının korunduğu tespit edilmiştir. Numunelere uygulanan düşük hızlı darbe deney sonuçları incelendiğinde gaz nitrürlenmiş numunelerin, su verme sertleştirmesi uygulanmış numunelere göre daha yüksek darbe direncine sahip olduğu tespit edilmiştir.

Anahtar kelimeler: Gaz nitrürleme, Isıl işlem, Malzeme bilimi, Su verme, Tabanca namlusu

\begin{abstract}
Defense industry has been an indispensable area for countries, and its importance has been increasing day by day. Within this scope, as in most fields of industry, improvement works in the defense industry have gained speed in recent years. In this study, it was aimed to contribute to the development of the defense industry technology of our country and to create knowledge in the field of defense industry. Barrel is one of the primary parts that directly affect the lifetime of the gun in light weapons. In this respect, the heat treatment to be applied to the gun barrel directly affects the lifetime of the gun. In this study, 2 types of heat treatment namely the traditional quenching process applied to the barrels and the gas nitration method whose application area has expanded in recent years, were applied to the samples created from 32CrMoV12-10 (1.7765) material, which is widely used as barrel material, and effects of these applications on samples were experimentally studied. When the results of the experimental studies were examined, it was determined that the surface hardness of the gas-nitrided samples was approximately 1.5 times higher than the samples that were quenched, whereas the internal structure was preserved. When the low velocity impact test results applied to the samples were examined, it was determined that the gas nitrided samples had higher impact resistance compared to the samples that applied quenching hardening.
\end{abstract}

Keywords: Gas nitriding, Heat treatment, Materials science, Quench hardening, Gun barrel

\footnotetext{
${ }^{*}$ a Mahmutcan KARSLI; mahmut.cann@hotmail.com, Tel: (0506) 45847 75, orcid.org/0000-0002-8729-7497

${ }^{\mathrm{b}}$ orcid.org/0000-0002-5597-1256 $\quad{ }^{\mathrm{c}}$ orcid.org/0000-0002-6912-279X
} 


\section{Giriş}

Malzemelerin özelliklerinin belirlenmesinde uygulanan imalat yöntemleri, yüzey kaplama yöntemleri ve uygulanan 1 sıl işlem yöntemlerinin çok önemli rol aldığı bildirilmektedir (Saklakoğlu vd., 2016). $\mathrm{Bu}$ nedenle, malzeme seçiminde uygulanan imalat yöntemi ve uygulanacak 1s1 işlem metotları istenilen özellikleri taşıması açısından önem arz etmekte olup, uygun proses ve parametreler dikkatlice belirlenmelidir. Seçilen yöntemlerin ve parametrelerin malzeme yüzeylerinin sertleştirme işlemlerini de belirlediği bildirilmektedir (Toktaş vd., 2017). Malzemelerin sertlik özelliklerinin incelenmesi üzerine çeşitli çalışmalar yapılmıştır. Bu çalışmalardan bazıları sinterleme yöntemi ile elde edilen malzemelerin sertliğinin incelenmesi üzerine iken; bazıları da aşınma sertliğinin incelenmesi olduğu belirtilmektedir (Karakulak, 2017; Y1lmaz, 2019).

Silahların tarihsel gelişim sürecinde teknolojik gelişmelere paralel olarak geliştirildiği ve bu sayede silahtan beklenilen yüksek mukavemet, düşük ağırlık, yüksek aşınma ve korozyon direnci gibi özellikleri giderek daha da iyileştirildiği gözlemlenmektedir. Yapılan çalışmalarda silah parçalarının yüksek gerilmeli yüklere maruz kaldıkları için parçaların imalatlarında kullanılacak malzemelerin yüksek mukavemet değerlerine sahip olması gerektiği, bu özellik sayesinde de kullanım süresince şekilsel değişimin kabul edilebilir sınırlar içerisinde kalmasının sağlanması bunun sonucunda ise kullanım ömrünün artırılması hedeflenmektedir. $\mathrm{Bu}$ nedenle yüksek boyutsal kararlılıkta uzun ömür elde edilmesi için silah parçalarında seçilecek olan malzemelerin yüksek mukavemete ve yüksek darbe direncine sahip olmaları gerektiği belirtilmektedir (Karsl1, 2016; Yavuz, 2018; Göksu, 2015).

Son y1llarda yurtiçi ve yurtdışı silah alım şartnamelerinde silah atım ömürlerinin belirlenen dünya standartlarının üzerine çıkması, başta namlu olmak üzere tabanca parçaları üzerinde geliştirme çalışmaların yapılmasını zorunlu kılmıştır. Özellikle de kolluk kuvvetleri silah alımlarını yaparken atım ömürlerinin minimum 50.000 atım seviyelerinde olmasinı talep etmektedirler. $\mathrm{Bu}$ atım ömrünü sağlayabilmek için tabanca parçalarında malzeme, 1sıl işlem ve kaplama gibi parçaların ömrüne doğrudan etki eden parametrelerin optimum seviyede seçilmesi gerektiği bildirilmektedir (Rutci, 2019). Tabanca namluları hakkında yapılan bir çalışmada, 1.2340 sıcak iş takım çeliği malzemesinden üretilen namluyu, AISI 4140 malzemesinden üretilen namlu ile kıyaslamış ve namlu numunelerine çeşitli deneysel çalışmalar yapmıştır. Yapılan deneyler sonucunda 1.2340 sıcak iş takım çeliğinden üretilen namlunun AISI 4140 malzemesinden üretilen namluya göre daha uzun ömürlü olduğu tespit edilmiştir. 1.2340 malzemesinden üretilen namluların ömür değerlerinin yaklaşık \%66 arttığını, ayrıca aşınma dayanımının ve dolayısıyla dağılım performansının iyileştiğini belirtilmiştir. Yapılan bu çalışmada namlu deneysel çalışmalarının yanında üretilen numune namluları tabanca olarak da denenmesi amacıyla çeşitli atış testleri uygulanmıştır. Yapılan atış testlerinin sonucuna göre, AISI 4140 malzemesinden yapılan polimer gövdeli tabancaların namlu ömürleri 30.000 atım olarak belirlenmiş olup, 1.2340 sicak iş takım çeliğinden üretilen namlunun ömür değeri 50.000 atım olarak belirlenmiştir (Rutci, 2019).

$36 \mathrm{CrB} 4$ ve $42 \mathrm{CrMo} 4$ çeliklerde 1 s1l işlemin mekanik özelliklere etkilerinin incelendiği farklı bir çalışmada, bu iki malzemeyi farklı sıcaklıklarda menevişleme (temperleme) işlemine tabi tutarak, optimum 1sıl işlem sıcaklığı belirlemiş olup malzemelerden hazırlanan numunelerin mekanik özelliklerini belirlemek için çeşitli deneyler yapmıştır. Yapılan deneysel çalışmaların sonucunda, menevişleme sicaklığının değiştirilmesi ile 36CrB4 malzemesinin 42CrMo4 malzemesinin mekanik özelliklerine sahip olabileceği tespit edilmiş olup $42 \mathrm{CrMo} 4$ malzemesinin yerine $36 \mathrm{CrB} 4$ malzemesinin kullanılması halinde maliyet açısından tasarruf sağlanacağı ve malzeme kullanımındaki farklılıkların ortadan kalkacağı belirtilmiştir (Dokuzlar, 2018).

Yapılan farklı bir çalı̧̧mada ise X40CrMoV51 sicak iş çeliğine önce su verme ve temperleme, ardından iyon nitrürleme işlemlerini uygulamıştır. Çalışmada bu numunelerin sertlik değerleri ve $\mathrm{X}$ 1şını Difraksiyon analizleri incelenmiştir. İyon nitrürlenmiş çeliğin yüzey sertliğinin, yalnızca su verilmiş ve temperlenmiş çeliğinkinden yaklaşık iki kat daha fazla olduğu saptanmıştır. Sertliğin önemli olduğu iş parçalarında iyon nitrürleme işleminin yapılması ömür artışı için önemli olduğu belirtilmiştir (Baycık, 2002).

Diğer bir çalışmada ise, DIN 1.3343, DIN 1.3243 ve DIN 1.3247 yüksek hız çeliklerini, sertleştirme ve temperleme işlemlerinin ardından nitrasyona tabi tutarak, oda sicaklığında ve yüksek sıcaklıklarda aşınma dayanımını incelenmiştir. Numunelere yapılan deneylerin ardından aynı kompozisyona sahip malzemelerin deneyleri incelendiğinde, uygulanan farklı aşınma test 
sıcaklıklarında nitrasyonlu numunelerin nitrasyonsuz numunelere göre daha az aşındığ 1 tespit edilmiştir. Ayrıca malzemelerin sertliğindeki artışın, aşınma dayanımını olumlu yünde etkilediği görülmüştür (Bostan, 2015).

Güven ve arkadaşları yaptıkları çalışmada AISI 4140 malzemeye $450{ }^{\circ} \mathrm{C}$ ' de 2 farklı sürede (18 ve 19.5 saat) iyon nitrürleme (Plazma nitrasyon) yüzey sertleştirme işlemi uygulayıp farklı yüklerde yorulma dayanımlarını incelemişlerdir. Ayrıca numunelerin sertlik değerleri ölçülmüş olup herhangi bir yüzey işlemi uygulanmamış AISI 4140 çeliğinin ortalama sertliği $221 \mathrm{HV}$ olarak tespit edilmiştir. Yüzey sertleştirilmesi yapılan numunelerin sertlik değerleri de ölçülmüş, 18 saat iyon nitrürleme işlemi yapılan numunenin yüzey sertliği ortalama $522 \mathrm{HV}, 19.5$ saat iyon nitrürleme işlemi yapılan numunenin yüzey sertliği ise ortalama 557 HV olarak ölçüldüğü bildirilmiştir. Sertlik ölçüm sonuçlarına göre, iyon nitrürleme işlem süresinin artması, yüzey sertliğini yaklaşı \% 6 oranında arttırmıştır. Dönen eğmeli yorulma deney sonuçları incelendiğinde ise 19.5 saat iyon nitrürleme işlemi uygulanmış numunelerle 18 saat iyon nitrürleme uygulanmış numunelerin yorulma dayanımlarında fazla bir fark olmadığ 1 ancak, hiçbir işlem görmeyen numunelere göre, yorulma dayanımlarında belirgin bir artış olduğu saptanmıştır (Güven vd., 2014).

Is1l işlem yöntemiyle sertleştirmeye yönelik olarak yapılan işlemlerde korozyon direnci sağlayan nikel alaşımlı sünek dökme demirlerin mikro yapı ve mekanik özellikleri üzerindeki etkilerini incelendiği bir çalışmada, $900{ }^{\circ} \mathrm{C}$ ve $1000^{\circ} \mathrm{C}$ de aynı sürelerde 1 sıl işlem uygulanan numunelere su verme ve havada soğutma işlemleri uygulanıp, soğuma hızının etkileri incelenmiştir. Elde edilen numunelerin mikro yapıları incelendiğinde farklı soğutma hızlarının mikro yapılar üzerinde etkili olduğu ve farklı mikro yapıların meydana geldiğini rapor edilmiştir (Yeşiltepe ve Şeşen, 2017).

Literatürdeki tüm bu çalışmalar incelendiğinde, optimum mekanik özelliklerin elde edilmesi amaciyla, her malzemeye uygulanacak olan 1s1 işlem yönteminin farklı olduğu ve yapılacak en uygun yöntem ve parametrelerin belirlenmesinin de malzemeler için önem arz ettiği tespit edilmiştir. Bununla birlikte, literatür araştırmaları sonucunda çelik malzemelerin kimyasal özellikler değiştirilmeksizin, 1sıl işlem uygulanarak malzemelerin mekanik özellikleri iyileştirilebileceği de görülmektedir.

$\mathrm{Bu}$ çalışmada tabanca ana parçalarından biri olan namluyu temsilen dövülmüş haldeki 32CrMoV1210 malzemeden numuneler hazırlanmış, hazırlanan bu numunelere hali hazırda tabanca namlularına uygulanan geleneksel su verme sertleştirmesi ve buna karşılık son yıllarda uygulama alanı genişleyen gaz nitrürleme işlemi uygulanmıştır. Sertleştirme işlemi uygulanan numunelerin mikro yapısının incelenmesi, sertlik deneyi ve darbe deneyi uygulanarak, bu deneysel çalışmalara göre sonuçların değerlendirilmesi ve bu sayede ülkemiz savunma sanayi bilgi birikimine katkı sağlanması hedeflenmiştir.

Şekil 1' de hafif silahlar grubuna dahil olan örnek bir tabanca namlusunun tasarımı ve fotoğrafi verilmiştir.
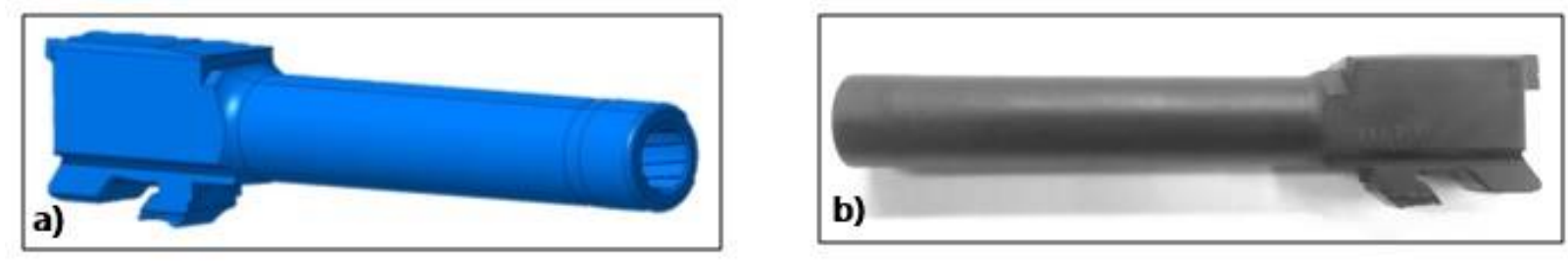

Şekil 1. Tabanca namlusu; a) Namlu tasarımı (GİR-SAN, 2020), b) Namlu örneği (GİR-SAN, 2020)

Namlu parçası belirli bir atım sayısının ardından yiv-setlerinde meydana gelen aşınma ve bu aşınmaya bağlı olarak ortaya çıkan olumsuz dağılım (grupman) etkisi sebebiyle tabancanın ömrünü belirleyen en önemli parçaların başında gelmektedir. Yurtiçi ve yurtdışı silah alım şartnamelerinde silah ömrünü belirleyen en önemli kriterlerden birisi dağılım testidir. Tabancaların şartnamelerde belirlenen atım sayılarına ulaşmalarının ardından yapılan dağılım testleri ile atım öncesinde yapılan dağılım testlerindeki performansına eş bir değer performans beklenmektedir. $\mathrm{Bu}$ performans tabanca namlusunun tabancanın ömrünü belirleyen en önemli kriterlerden biridir. Bunun yanında tabancanın tasarımına bağlı olarak namlunun kapak (sürgü) parçasından gelen darbeyi karşılaması da beklenmektedir. Her atımda namlu haznesinde patlayan merminin basinc yardımı ile kapak geri gelme hareketine başlayarak namluyu 
geri itmekte ve her atımda namluya darbe uygulamaktadır. Namlu, kapağın her atımdaki darbesini karş1lamakla birlikte sistemin hareketine de ayak uydurmaktadır. Görüleceği üzere tabancanın çalışma fonksiyonunda kritik etkileri olan namlunun ömür geliştirme çalışmalarının yapılması savunma sanayi açısından büyük önem arz etmektedir (Karsl1, 2016; Gürel vd., 2020)

Yapılan bu çalışmada dövme yöntemi ile elde edilen 32CrMoV12-10 (1.7765) hammaddeden namluyu temsil etmek üzere, talaşlı imalat yöntemi ile oluşturulmuş plaka şeklindeki numuneler kullanılmış olup numunelere su verme sertleştirmesi (kitle sertliği) ve gaz nitrasyon isıl işlem yöntemleri olmak üzere iki farklı sertleştirme uygulanmıştır. Numunelere uygulanan sertleştirme işlemlerinin numuneler üzerinde oluşturduğu mekanik etkilerin incelenmesi amaciyla mikro sertlik ölçümleri ve serbest düşme darbe deneyleri yapılmıştır.

\section{Materyal ve method}

Silah namlusu üretiminde yaygın olarak kullanılan, soğuk dövme yöntemi ile 32CrMoV12-10 malzemesinden elde edilen hammaddeden, talaşlı imalat yöntemi kullanılarak plaka şeklinde numuneler oluşturulmus, elde edilen numunelere su verme sertleştirmesi (sertleştirme + meneviş) ve gaz nitrasyon (kontrollü gaz nitrasyon + oksidasyon) 1sıl işlem yöntemleri olmak üzere iki tip sertleştirme uygulanmıştır. Sonrasında bu sertleştirme işlemlerinin numuneler üzerinde oluşturduğu etkilerin deneysel karşılaş̧tırılması yapılmıştır. Numunelerde kullanılan 32CrMoV1210 namlu malzemesinin kimyasal analizi Tablo 1' de, TTT diyagramı Şekil 2'de, deney numunesi örneği de Şekil 3' te verilmiştir.

Tablo 1. 32CrMoV12-10 malzemenin kimyasal analizi (\% Ağırlıkça) (SİJ, 2020)

\begin{tabular}{|l|l|l|l|l|l|l|l|l|}
\hline $\mathrm{C}$ & $\mathrm{Si}$ & $\mathrm{Mn}$ & $\mathrm{Cr}$ & $\mathrm{Mo}$ & $\mathrm{Ni}$ & $\mathrm{V}$ & $\mathrm{W}$ & Others \\
\hline 0.32 & $\max .0 .35$ & $\max .0 .60$ & 3.00 & 1.00 & - & 0.30 & - & - \\
\hline
\end{tabular}

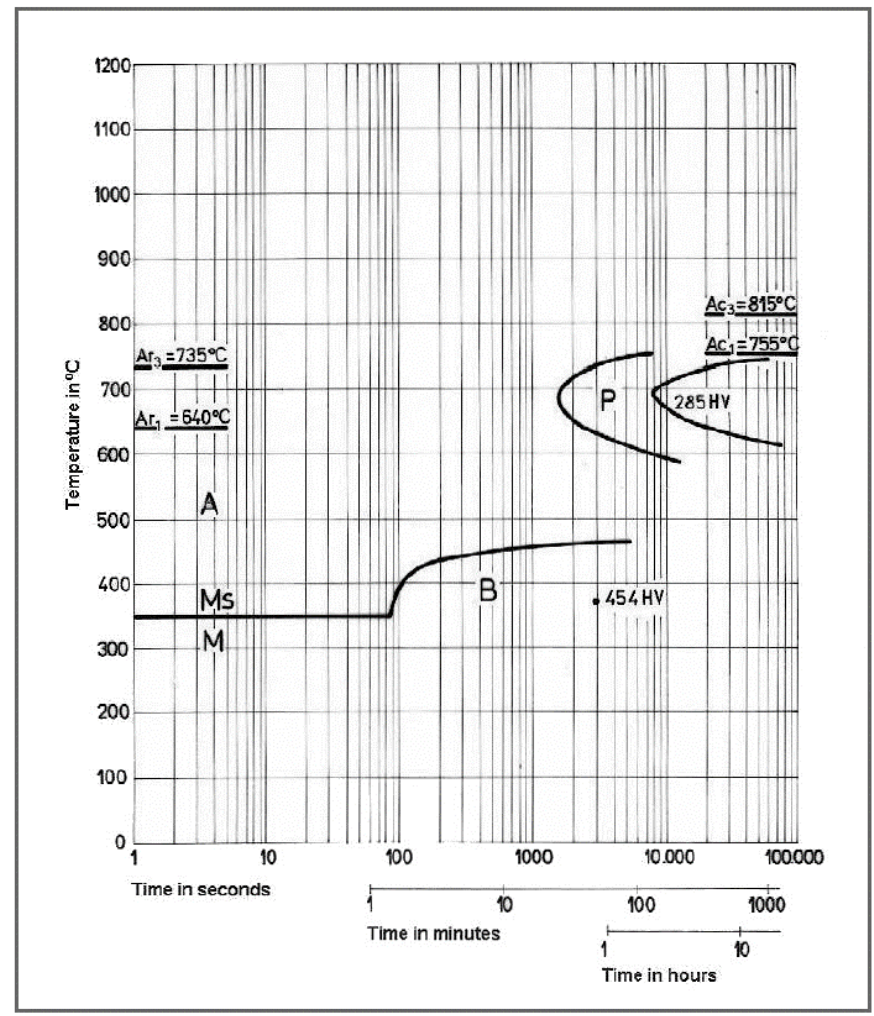

Şekil 2. 32CrMoV12-10 TTT diyagramı (SİJ, 2020) 


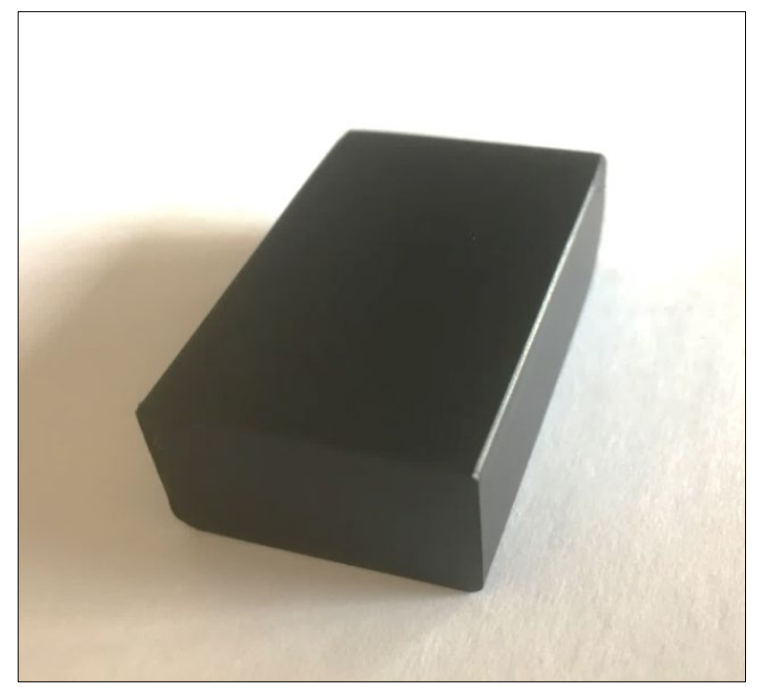

Şekil 3. Nitrasyon ve oksidasyon işlemleri uygulanmış numune

Is1l işlem yöntemleri, metal veya alaşımlara istenilen özellikleri kazandırmak amacıyla yüksek teknoloji gerektiren donanım ve kontrol teknikleri ile katı halde uygulanan kontrollü 1sitma ve soğutma işlemleri olarak tanımlanmaktadır. Uygulanacak 1sıl işlem, hem malzemenin mikro yapısını iyileştirmeli, hem de malzemeye, o malzemede olması arzulanan mekanik özellikleri kazandırmalıdır. Bunlarla birlikte, uygulanan 1s1 işlem ve yüzey işlemleri, malzemeden veya makine elemanından beklenen performansa uygun bir şekilde gerçekleştirilmelidir. Örneğin, silahlar yüksek şiddetli ve tekrarlı darbe yükleri altında çalıştıklarından dolayı kullanılan silahın uzun ömürlü olması ve kullanıcıya uzun süre hizmet verebilmesi için tabanca parçalarının darbe dayanımlarının yüksek olması istenmektedir (Karsl1, 2016). Makine parçaları fonksiyonları gereği değişken yüklere maruz kalırlar ve belirli bir yük tekrarından sonra yorulma sonucu kırılarak hasara uğrarlar. Yüzey sertleştirme işlemleri makine parçalarının yorulma dayanımlarını yükselterek kullanım ömürlerini uzatabilir (Güven vd., 2014).

Isıl işlem yöntemlerinden biri olan su verme işlemi en basit şekliyle, malzemenin sertleştirme sıcaklığına kadar isitılması ve ani olarak soğutulmasıyla sertleştirilmesi olarak tanımlanabilir. Yapılan bu işlem, malzemenin belirli sıcaklığa kadar 1sıtılması ve burada uniform bir içyapının elde edilmesi için belirli süre bekletilmesi son aşamada oda sıcaklığına ani olarak soğutulması olarak üç bölümde gerçekleştirilir. Hızlı soğuma neticesinde karbon atomları difüzyon ile katı çözeltiden ayrılmak için yeterli vakit bulamadıklarından çözelti içine hapsedilerek HMK yapıya dönüşemez ve yeni bir yap1 olan martenzitik yapı elde edilmiş olur. Martenzitik yapının oluşumu esnasında meydana gelen hacimsel büyüme çok yüksek ölçüde gerilmeler oluşturur ve matris yapısını aşırı derecede çarpılmasını sağlar. Kafes yapısındaki bu çarpılma dislokasyon hareketlerini engelleyerek veya zorlayarak su verme işlemiyle yüksek sertlik ve mukavemet elde edilmesini sağlar (Çakır, 2008; Savaşkan, 2007). Bu çalışmada numunelere uygulanan su verme işleminin parametre ve adımları Tablo 2' de verilmiştir.

Tablo 2. Numunelere uygulanan su verme sertleştirmesi parametreleri

\begin{tabular}{|l|l|}
\hline \multicolumn{2}{|l|}{ Su verme sertleştirmesi } \\
\hline $850{ }^{\circ} \mathrm{C}$ & $50 \mathrm{dk}$ \\
\hline Menevişleme \\
\hline $550{ }^{\circ} \mathrm{C}$ & $180 \mathrm{dk}$ \\
\hline Tuz sıcaklığı: $180{ }^{\circ} \mathrm{C}$ \\
\hline
\end{tabular}

Nitrasyon, düşük sıcaklık yüzey sertleştirme işlemlerinden birisi olup çelik parça yüzeyine azot atomlarının ara yer atomu olarak gönderilmesi ile yüzeyde sert bir tabakanın (beyaz tabaka) oluşturulması esasına dayanır. Azot sağlayıcı ortam olarak tuz banyosu ve gaz atmosferi kullanılabilir. Nitrasyon işleminde sert tabakanın (beyaz tabaka) oluşması için yükssek hızda soğutma hızı gerekmez (Polat, 2011; Karcan, 2005). Şekil 4 'te gaz nitrasyon işlemi uygulanmış AISI4140 ve DIN 1.2344 malzemelerin beyaz tabaka oluşumunu gösteren optik mikroskop görüntüleri verilmiştir. 

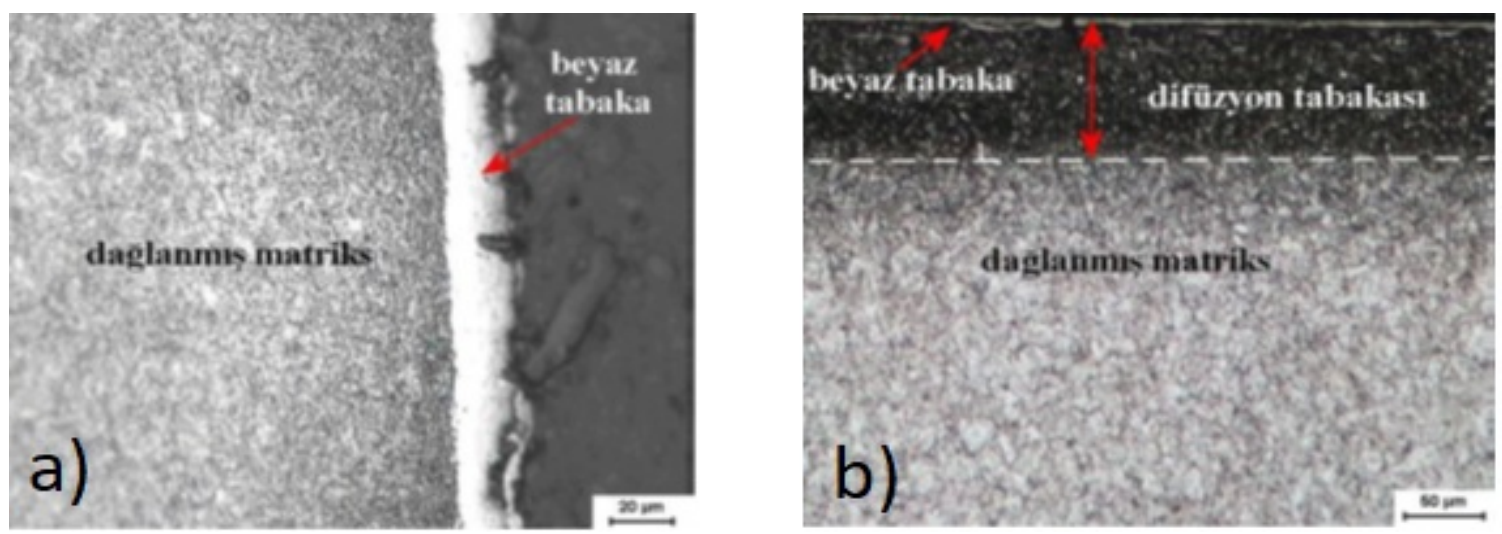

Şekil 4. a) AISI4140 malzemede oluşan beyaz tabakanın görünümü, b) DIN 1.2344 malzemede oluşan beyaz tabakanın görünümü (Polat, 2011)

Nitrasyon işleminde proses gaz ortamında nitrasyon sicaklığında azotun malzemenin yüzeyinden merkeze doğru nufüz etmesi şeklinde gerçekleşir. Azot, demir ve alaşım elementleri ile reaksiyona girerek nitrür oluşturur ve bu sayede sert bir yap1 elde edilir. Yüzeyden merkeze doğru ilerleyen azot difüzyonunun sağlanması ile yüzey sertliğinde orijinal sertlikten çok daha yüksek sertlik değerlerine ulaşılabilmektedir Teknik olarak nitrasyon işlemi $\alpha$-Fe fazında, $590{ }^{\circ} \mathrm{C}$ sıcaklığında maksimum \%0.115 azot çözünürlüğü sağlayacak şekilde uygulanmaktadır (Polat, 2011). $\mathrm{Su}$ verme sertleştirmesine kıyasla daha düşük sicaklıkta uygulanması ve yüksek soğuma hızı gerektirmemesi nedeni ile parçalarda çarpılma minimum seviyededir. Nitrasyon, yüksek yüzey sertliği, artan aşınma direnci, yorulma ömründe artış ve yüksek korozyon direnci avantajları sayesinde son yıllarda özellikle savunma sanayisinde tercih edilen sertleştirme metotlarının başında gelmektedir. Numunelere kontrollü ortamda gaz nitrasyon işlemi uygulanmış olup parametre ve adımları Tablo 3' te verilmiştir.

Tablo 3. Numunelere uygulanan nitrasyon işleminin parametreleri ve adımları

\begin{tabular}{|l|l|}
\hline \multicolumn{2}{|l|}{ Gaz nitrasyon ısıl işlemi ve oksidasyon } \\
\hline 1 & $200{ }^{\circ} \mathrm{C}^{\prime}$ de Ön Isıtma \\
\hline 2 & $580{ }^{\circ} \mathrm{C}^{\prime}$ ye Kademeli Isıtma \\
\hline 3 & $580{ }^{\circ} \mathrm{C}^{\prime}$ de 180 dk tutularak Nitrasyon \\
\hline 4 & $580{ }^{\circ} \mathrm{C}^{\prime}$ den Kademeli Olarak Soğutma \\
\hline 5 & Oksidasyon \\
\hline
\end{tabular}

$\mathrm{Bu}$ çalışma kapsamında yapılan gaz nitrasyon işlemi kontrollü ortamda yapılmış olup, konuyla ilgili daha önce yapılan $32 \mathrm{CrMoV}$ çeliğinin aşınma direncini arttırmak için yeni bir ısıl işlem yöntemi geliştirilmesi çalışması kapsamında, yüzey sertleştirme işlemleri boyunca, malzemenin oksitlenmemesinin kontrol edilmesi gereken en önemli faktörlerden biri olduğunu belirtilmiştir. Oksijenin çelik içinde yayınımı ile malzemenin kırılganlığ1 artmakta ve darbelere karşı dayanımının azaldığı bu nedenle uygulanacak isıl işlem proseslerinde kontrollü atmosferde yapılmasının bu olumsuz etkileri önleyeceği bildirilmiştir (Özcan, 2012).

Nitrasyon sonrası parçalara uygulanan oksidasyon işlemi parçaya siyah bir görünüm kazandırmasının yanında parçaya yapılacak boya veya diğer kaplama işlemlerinin daha iyi tutunmasını ve daha uzun ömürlü olmasını sağlar. Hatta oksidasyon işlemi ile sağlanan renk tonu istenilen kıvamda ise herhangi bir kaplama işlemi yapmadan parça oksidasyonlu olarak da kullanılabilir, bu da günümüz rekabet koşullarında düşük maliyet elde edilmesini açısından avantaj sağlamaktadır (ALPER, 2020).

\section{Bulgular}

Bu çalışma kapsamında, su verme (kitle sertlik) sertleştirmesi ve gaz nitrürleme (Nitrasyon) uygulanan numunelerin sertlik ölçümleri yapılmış, numunelere düşük hızda darbe deneyleri uygulanarak numunelere etki eden kuvvet değerleri saptanmış ve absorbe edilen enerji değerleri yorumlanarak numunelerin darbe dayanımları karşılaştırılmıştır. Saptanan kuvvet değerleri, geliştirilen namlu malzemesinin sınır değerlerinin belirlenmesini sağlamıştır.

Yapılan yüzey iyileştirme işlemleri sonrasında sertlik ölçüm sonuçları Tablo 4 ve 5 ile Şekil 5'te sırası ile verilmiştir. Su verme sertleştirmesi uygulanan numunelere AFFRI 206 EX model 
sertlik ölçüm cihazında sertlik ölçümleri yapılmıştır. Nitrürlenmiş numunelerin sertlik ölçümleri ise numunelerden kesilen parçaların bakalite alınarak laboratuvar ortamında hazırlanarak Microvickers cihazında mikroskop incelenmesiyle üç farklı noktadan alınan verilerin ortalaması belirlenerek yapılmıştır.

Tablo 4. Su verme sertleştirmesi yapılan numunelerin sertlik ölçüm sonuçları

\begin{tabular}{|l|l|l|}
\hline Numune & Sertlik & Skala \\
\hline 1 & $490 \pm 2$ & HV \\
\hline 2 & $495 \pm 2$ & HV \\
\hline 3 & $495 \pm 2$ & HV \\
\hline
\end{tabular}

$\mathrm{Su}$ verme sertleştirmesi uygulanan numunelerin sertlik ölçüm sonuçları incelendiğinde numunelerin ortalama 493 HV (Yaklaşık 49 HRC) kitle sertliğine sahip oldukları tespit edilmiştir.

Tablo 5. Gaz nitrürlenmiş numunenin mikrosertlik ölçüm sonuçları

\begin{tabular}{|l|l|l|}
\hline \multicolumn{3}{|l|}{ Beyaz tabaka: $5 \mu \mathrm{m}$} \\
\hline Derinlik $(\mathrm{mm})$ & Sertlik & Skala \\
\hline Yüzey & $800 \pm 2$ & HV \\
\hline 0.05 & $443 \pm 2$ & HV \\
\hline 0.1 & $368 \pm 2$ & HV \\
\hline 6.4 & $330 \pm 2$ & HV \\
\hline
\end{tabular}

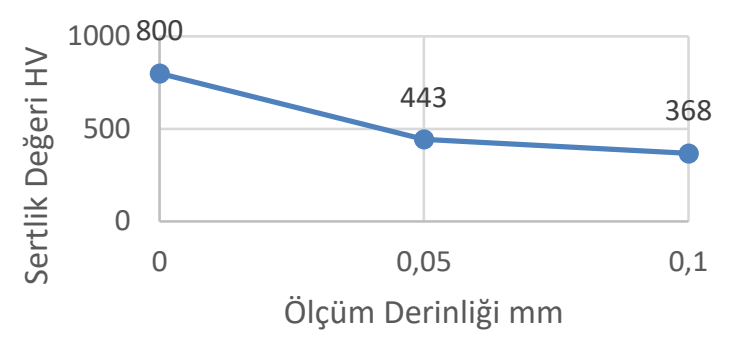

Şekil 5. Gaz nitrürlenmiş numunenin mikrosertlik ölçümlerinin grafiği

Gaz nitrürleme ve sonrasında oksidasyon işlemleri uygulanan numunelere yapılan mikrosertlik deneyi sonucu $5 \mu \mathrm{m}$ derinliğinde beyaz tabaka tespit edilmiştir. Mikrosertlik ölçüm sonucuna bakıldığında numunelerin çekirdek sertlikleri 330 $\mathrm{HV}$ olduğu dış yüzeylerinin ise (yaklaşık $2.5 \mathrm{~kat}$ daha sert) $800 \mathrm{HV}$ olduğu tespit edilmiştir. Yüzey sertleştirme yöntemlerinde dikkat edilmesi gereken en kritik detaylardan birisinin yüzeyi sertleştirirken, yüzeyden iç tarafa doğru ilerledikçe malzemenin asıl özelliklerinden mümkün olduğunca az ödün vermek olduğunu belirtmiştir. Malzeme yüzeyinin sert, yüzeyden içeriye gidildikçe sünekliliğin yüksek olması gerektiğini vurgulamıştır. AISI4140 ve DIN1.2344 malzemelerin gaz nitrasyon ile yüzey sertleştirilmesi konusunda yapılan çalışmada sertliklerinin karşılaştırıldı ğı, her iki numunenin de yüzeylerinin orijinal halinden daha yüksek sertlikte oldukları, yüzeyden içeri doğru ilerledikçe sertliğin düştüğü fakat 1.2344 malzemede difüzyon tabakası boyunca sert nitrür fazların fazla olması sebebiyle sertlik değerlerinin fazla olduğu bildirilmiştir (Özcan, 2012; Polat 2011). Bu nedenle uygulanan metotlarda, malzemenin yüzeyini sertleştirirken tokluğunu korumak en önemli hedeflerden biridir. Bunun için metot mümkün olduğunca düşük sicaklıklarda uygulanmalı ve yüzeyden uzaklaşıldıkça mikro yapının değişimi minimuma indirilmelidir. Şekil 6'da namlu malzemesi olarak yaygin olarak kullanılan 32CrMoV12-10 malzemesine gaz nitrasyon işlemi uygulanması sonucu elde edilen beyaz tabakanın SEM görüntüsü verilmiştir.

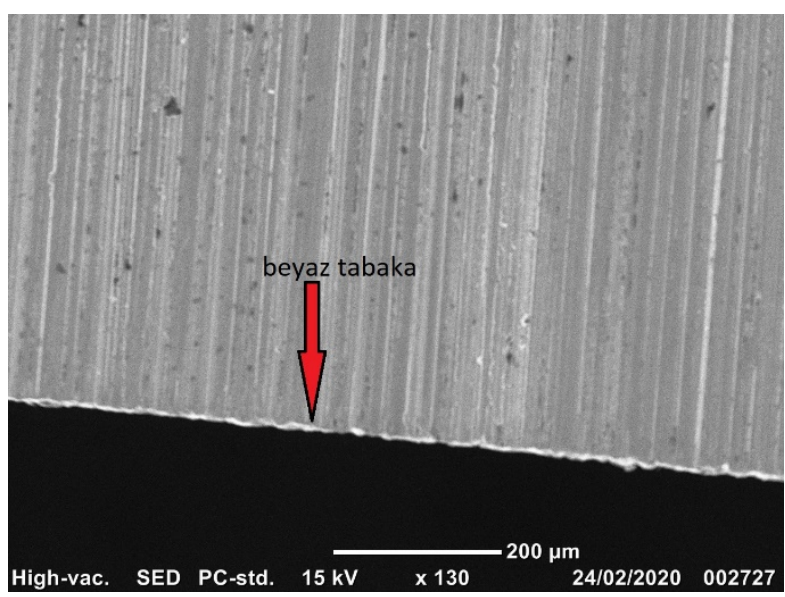

Şekil 6. 32CrMoV12-10 namlu malzemesinin gaz nitrasyon işlemi sonrası oluşan beyaz tabakanın SEM görüntüsü

Gaz nitrürleme işlemi yapılan numunelerin yüzey sertliklerinin, su verme işlemi uygulanan numunelerden yaklaşı 1.5 kat daha fazla olduğu buna karş1lı gaz nitrürlenmiş numunelerin çekirdeklerinde su verme uygulanmış numunelere göre daha sünek bir yapıya sahip oldukları görülmektedir. Bu sebeple nitrürlenmiş numunenin yüzeyinin daha sert oluşu aşınma dayanımını arttracak, dolayısıyla tabanca namlusunun atım ömründe de artış sağlanacaktır. 
Yüzey sertleştirme işlemi yapılan numunelere ağırlık düşürme tekniği ile çalışan CEAST Fractovis Plus markalı darbe cihazı ile 20 ve 30 Joule enerjiye sahip düşük hızlı darbe deneyleri uygulanmıştır. Yapılan darbe deneyinde her bir numune için üç tekrar yapılarak elde edilen sonuçların ortalaması alınmıştır. Deneylere başlanmadan önceki ön çalışmalar kapsamında 20 ve 30 Joule enerji seviyelerinde darbe deneylerinin

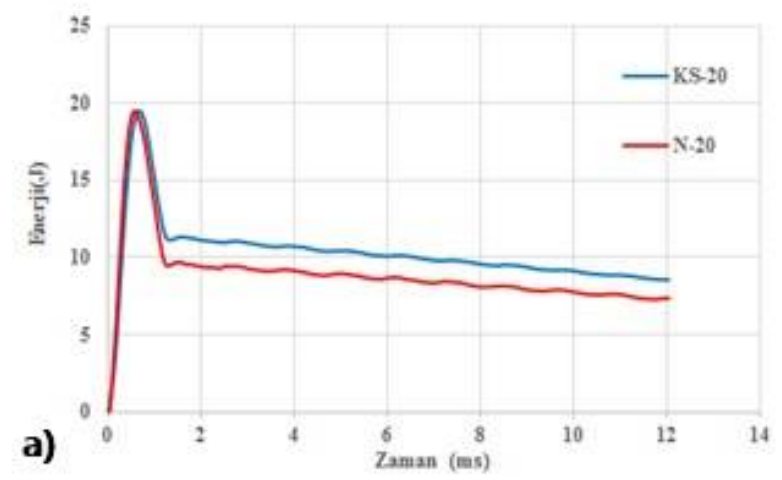

uygulanma nedenleri, namlu malzemelerinin bu değer aralıklarındaki enerji seviyelerine maruz kalmalarından dolayıdır. $\mathrm{Bu}$ sebeple, namlu malzemelerinin darbe enerjilerine karş1 20 ila 30 Joule aralığında gösterdikleri karakteristik özellik bu çalışma bakımından oldukça önemlidir. Darbe deneylerinden elde edilen enerji - zaman ve kuvvet - zaman diyagramları sırasıyla Şekil 7 ve 8 ' de gösterilmektedir.

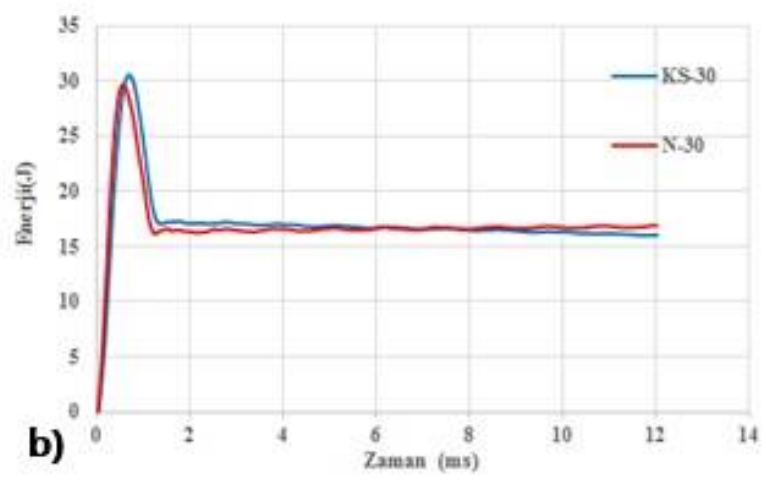

Şekil 7. Düşük hızlı darbe sonrası elde edilen Enerji - Zaman diyagramları: a) 20 Joule, b) 30 Joule

Şekil 7' te gösterilen enerji - zaman diyagramlarından da görüldüğü üzere; 20 Joule enerji uygulanan numunelerde, gaz nitrasyon yöntemi $(\mathrm{N})$ ile sertleştirilen numunelerin absorbe ettiği enerji 9 Joule iken, su verme işlemi (Kitle sertliği - KS) ile sertleştirilen numunelerin absorbe ettiği enerji değerinin 11,5 Joule olduğu görülmektedir. Diyagramlardan da anlaşılacağ 1 üzere; 20 Joule enerji seviyesinde gaz nitrasyon yöntemi ile sertleştirilen numunelerin elastik enerji değerinin arttığı, buna bağlı olarak absorbe edilen enerji değerinin azaldığı görülmektedir.

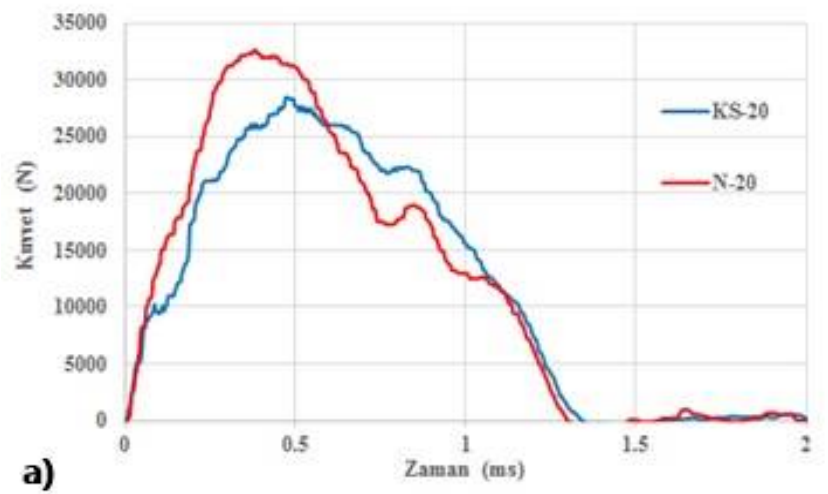

Numunelere 30 Joule enerji seviyesinde darbe uygulandığında su verme ve gaz nitrasyon yöntemleriyle sertleştirilen numunelerde enerji absorbasyon seviyelerinin birbirine yakın değerlerde ve yaklaşı 17 joule olduğu görülmektedir. 20 ve 30 Joule enerji seviyelerindeki darbe deneyi sonuçlarından her iki numune için elde edilen değerler incelendiğinde gaz nitrürlenmiş numunenin artan enerji seviyesi ile daha yüksek enerji absorbe etme kabiliyeti gösterdiği tespit edilmiştir.

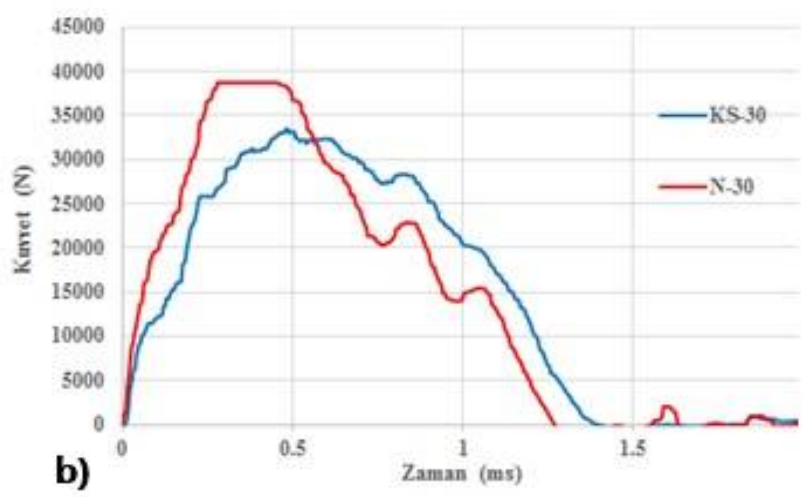

b) $\stackrel{1}{\text { Zaman }}(\mathrm{ms})$

Şekil 8. Düşük hızlı darbe sonrası elde edilen Kuvvet - Zaman diyagramları: a) 20 Joule, b) 30 Joule

Şekil 8' de verilen diyagramlar incelendiğinde, darbe testi uygulanan numunelerin kuvvet - zaman eğrileri parabolik bir eğriyi oluşturmaktadır. Burada, numunelere uygulanan 20 Joule değerindeki darbe enerjisi (Şekil 7a) ile 30 Joule değerindeki darbe enerjisi (Şekil 7.b) diyagramlanı karşılaştırıldığında, artan enerji değerine bağlı olarak numunelere etkiyen kuvvetin de arttığ görülmektedir. Her iki enerji değerinde de gaz nitrasyon ile sertleştirilen numunelere etkiyen 
kuvvetin daha fazla olduğu görülmektedir. Dolayısıyla gaz nitrürlenmiş numunenin kitle sertliği numunesine göre daha yüksek darbe direncine sahip olduğu belirlenmiştir.

\section{Tartışma ve sonuçlar}

$\mathrm{Bu}$ çalışmada, tabancalarda namlu malzemesi olarak kullanılan dövülmüş 32CrMoV12-10 çelik malzemeye uygulanan su verme ve gaz nitrasyon işlemlerinin mekanik özelliklere etkisi incelenmiştir. $\mathrm{Bu}$ amaçla, gerçekleştirilen isıl işlemlerden elde edilen bulgular yapılan deneysel çalışmalar yardımıyla irdelenmiştir.

Mikrosertlik ölçüm sonuçları incelendiğinde gaz nitrürleme işlemi yapılan numunelerin yüzey sertliklerinin, su verme işlemi uygulanan numunelerden yaklaşık 1.5 kat daha fazla olduğu buna karşılık numunelere yapılan kesitten sertlik ölçümü sonuçlarında nitrürlenmiş numunelerin çekirdeklerinde yüzeye göre yaklaşı 2.5 kat daha yumuşak bir yapıya sahip oldukları görülmektedir. Sertlik profilleri incelendiğinde, nitrürlenmiş numunelerde difüzyon tabakasının varlığı tespit edilmiştir. Nitrürlenmiş numunenin yüzeyinde oluşan yüksek sertlikteki beyaz tabaka, malzemenin aşınma performansına olumlu etki yapacak dolayisıyla tabanca namlusunun atım ömrünü arttıracaktır. Ayrıca yüksek yüzey sertliğine karşılık, çekirdekte sünek yapının korunması sayesinde tabanca namlusunun daha tok yapıda olduğu ve çekirdekte mikroyapı değişiminin su verilmiş numuneye göre daha az olduğu tespit edilmiştir. Nitrürlenmiş numunelerde yüksek yüzey sertliğinin elde edilmesinin yanı sıra malzemenin tokluğunun da korunuyor olması, su verme sertleştirme yöntemine kıyasla avantaj sağlarken, aynı zamanda namlu istenilen kalitede atım sayısını da artırmış olacaktır. Bu durum tabanca namlu parçasının ömrünü arttıracak önemli parametrelerden biridir.

Numunelere uygulanan düşük hızlı darbe deney sonuçları incelendiğinde gaz nitrasyon yöntemi ile sertleştirilen numunelerin elastik enerji değerinin geleneksel su verme (kitle sertliğine sahip) ile sertleştirilen numunelere kıyasla daha fazla olduğu, uygulanan düşük kuvvette absorbe edilen enerji değerinin daha az olduğu fakat uygulanan kuvvet arttıkça absorbe edilen enerji değerinin arttığı tespit edilmiştir. Ek olarak darbe deneyi neticesinde elde edilen kuvvet-zaman eğrilerinden elde edilen sonuçlardan gaz nitrürlenmiş numunelerin geleneksel kitle sertliği uygulanan numunelere kıyasla düşük ve yüksek olarak belirlenen deney yükleri karşısın da etkiyen kuvvetin daha yüksek olduğu görülmüştür. Bu sonuçlar neticesinde gaz nitrürlenmiş numunelerin daha yüksek yüzey sertliğine ve buna karşın daha yüksek darbe direncine sahip olduğu tespit edilmiştir.

\section{Kaynaklar}

ALPER- Alper Isı1 İşlem Tic. A.Ş. (2020, 07 Şubat), Erişim adresi https://www.alper.com.tr/.

Bostan, B. (2015). Yüksek hız takım çeliklerinin yüksek sıcaklık aşınma dayanımına nitrasyon işleminin etkisi. Yüksek Lisans Tezi, İstanbul Teknik Üniversitesi, Fen Bilimleri Enstitüsü, İstanbul.

Çakır, M. (2008). Su verme ısıl işleminde çelik-ortam arasindaki isl transferinin incelenmesi. Yüksek Lisans Tezi, Süleyman Demirel Üniversitesi, Fen Bilimleri Enstitüsü, Isparta.

Dokuzlar, Ö. (2018). 36CrB4 ve 42CrMo4 çeliklerde ısll işlemin mekanik özelliklere etkisinin araştırılması. Yüksek Lisans Tezi, Süleyman Demirel Üniversitesi, Fen Bilimleri Enstitüsü, Isparta.

GIRSAN, Girsan Makine ve Hafif Silah Sanayi Tic. A.Ş. $\quad(2020,03$ Şubat), Erişim adresi http://girsan.com.tr/.

Göksu, E. (2015). Türk kültüründe silah (2). Tokat: Otüken Yayıncılık.

Gürel, S., Yavuz, S., Karsl1, M. ve Altan, Ş.B. (2020). Hafif silahlarda kullanılan farklı kesit profiline sahip yerine getiren yayların yorulma davranışlarının incelenmesi. Recep Tayyip Erdoğan Üniversitesi Fen ve Mühendislik Bilimleri Dergisi, 1(2), 9-25.

Güven, Ş. Y., Delikanlı, K. ve Öncel, E. (2014). AISI 4140 çeliğine uygulanan iyon nitrasyon yüzey sertleştirme işleminin yorulma dayanımına etkisi. Süleyman Demirel Üniversitesi Teknik Bilimler Dergisi, 4(2), 29-39.

Karakulak, E. (2017). Toz metalurjik Cu-Ti malzemelerin sinterlenmesi ve karakterizasyonu. Celal Bayar Üniversitesi Fen Bilimleri Dergisi, 13(1), 245-250. https://doi.org/10.18466/cbayarfbe.302651.

Karcan, F. (2005). Sicak iş sübap kaliplarının ömürlerinin etüdü. Yüksek Lisans Tezi, İstanbul Teknik Üniversitesi, Fen Bilimleri Enstitüsü, İstanbul.

Karslı, M. (2016). Hafif silahlar için polimer kompozit malzeme seçimi. Yüksek Lisans Tezi, Karadeniz Teknik Üniversitesi, Fen Bilimleri Enstitüsü, Trabzon.

Özcan, H. (2012). 32CrMoV çeliğinin aşınma direncini arttırmak için yeni bir usıl işlem metodunun 
geliştirilmesi. Yüksek Lisans Tezi, Hacettepe Üniversitesi, Fen Bilimleri Enstitüsü, Ankara.

Polat, Ş., Atapek, H. Ş. ve Topaç, H. (2011). Gaz nitrasyon ile yüzeyi sertleştirilmiş AISI 4140 ve DIN 1.2344 çeliklerinde mikro yapısal karakterizasyon. International Advanced Technologies Symposium (IATS'11), 498-502, Elazığ.

Rutci, A. T. (2019). Hafif silahlarda kullanılan namlu malzemesinin geliştirilmesi ve işleme parametrelerinin incelenmesi. Yüksek Lisans Tezi, Sakarya Üniversitesi, Fen Bilimleri Enstitüsü, Sakarya.

Saklakoğlu, N., Gençalp İrizalp, S., İldaş, G. ve Demirok, S. (2016). Microstructure and wear properties of Fe-based hardfacing alloy / Feesaslı sert kaplama alaşımının mikroyapı ve aşınma özelliklerinin incelenmesi. Celal Bayar University Journal of Science, 12(3), 517-523.

Savaşkan, T. (2007). Malzeme Bilgisi ve Muayenesi (4). Trabzon: Celepler Matbaacılık.
SİJ Group, The SIJ - Slovenian Steel Group. (2020, 17 Şubat), Erişim adresi https://www.sij.si/en/sijbrands/sinoxx/.

Toktaş, G., Toktaş, A. and Duran, M. (2018). Investigating the wear behaviour of induction hardened 100Cr6 steel. Sakarya University Journal of Science, 22(5), 1174-1180. https://doi.org/10.16984/saufenbilder.304203.

Yavuz, S. (2018), Silah gövde malzemesi AA7075-T6 alaşımının anodik oksidasyonu. Yüksek Lisans Tezi, Karadeniz Teknik Üniversitesi, Fen Bilimleri Enstitüsü, Trabzon.

Yeşiltepe, S. ve Şeşen, M. K. (2017). Korozyona dayanıklı Ni alaşımlı sünek dökme demirlerde 1sıl işlemin küresel grafit, mikro yapı ve mekanik özelliklere etkisi. Mühendislik Bilimleri ve Tasarım Dergisi, 5(3), 479-482.

Yılmaz, E. Ç. (2019). Farklı ortam sıcaklıklarının kompozit restoratif malzemelerin mekanik ve tribolojik davranışları üzerindeki etkisinin incelenmesi. Afyon Kocatepe Üniversitesi Fen ve Mühendislik Bilimleri Dergisi, 19(1), 256-263. https://doi.org/10.35414/akufemubid.459904. 